\title{
Educational Solutions Amid a Moral Pandemic: Case Study at Islamic High School (MAN) 2 Kudus Boarding School
}

\author{
*Yunita Prasetyani ${ }^{1}$, Ashif Az-Zafi ${ }^{2}$ \\ ${ }^{1,2}$ Institut Agama Islam Negeri (IAIN) Kudus, Indonesia \\ *prasetyaniiyunitaa@gmail.com
}

\begin{abstract}
This article aims to understand how the process of moral education that is applied during the Covid-19 pandemic through the boarding school system at MAN 2 Kudus. And the research method used is qualitative (field research) using several sources. The results obtained are that the implementation of the moral education process in MAN 2 Kudus is through habituation in every daily activity, secondly teaching material and the yellow book, the third is through giving advice. The sixth is through providing rewards and punishments.
\end{abstract}

Naskah ini bertujuan untuk memahami bagaimana pendidikan akhlak diterapkan di masa pandemi Covid-19 melalui sistem pesantren di MAN 2 Kudus. Dan metode penelitian yang digunakan adalah kualitatif (penelitian lapangan) dengan menggunakan beberapa sumber. Hasil yang diperoleh bahwa pelaksanaan proses pendidikan akhlak di MAN 2 Kudus adalah melalui pembiasaan dalam setiap kegiatan sehari-hari, kedua bahan ajar dan kitab kuning, ketiga melalui pemberian nasehat dan keenam adalah melalui pemberian reward dan punishment.

Keywords: Boarding School, Solution, Morals, Pandemic.

Received: Maret 11, 2021; Revised: May 17, 2021; Accepted: June 20, 2021

\section{INTRODUCTION}

Learning remains an option for changing a person's behaviour because it is through the process that activity becomes an experience. Adaptation activities linked to learning activities can also change a person's behaviour due to environment-provided habituation (Houwer, Barnes-Holmes and Moors, 2013). According to Permendikbud (Minister of Education Regulation) No. 65, in the standard process, learning activities in schools begin with the preparation of learning plans, followed by the process or implementation of learning. Finally, the assessment of learning outcomes (Sugiyanto, Kartowagiran and Jailani, 2015). One of the learning materials taught at the level of formal education starting from elementary school, middle school to university and regulated by government regulations and fostered by the religious department is moral education (Tobroni, 2018).

Islamic education, especially moral education, is an essential concern in the world of education in Indonesia, especially as stated in the goal of the National Education System No. 20 of 2003, which reads education National Aims to develop the potential of students to become human beings who believe and fear God Almighty, have a noble character, are healthy, knowledgeable, capable, creative, independent, and become 
democratic and responsible citizens in the national education system Law, it is clear that one of the goals of education in Indonesia is to form the noble character of students. Here the role of schools as formal educational institutions is vital (Hutabarat, 2017).

The world of education is currently being shaken once more by the outbreak of the Covid-19 virus, which has declared a pandemic for most of the world. In response to this situation, the Minister of Education and Culture of the Republic of Indonesia issued Circular Letter No. 4 of 2020 concerning the implementation of education policies during the emergency period of the spread of Coronavirus Disease (Covid-19) that the learning process in all academic units is carried out from home via online or distance learning (Kementerian Pendidikan dan Kebudayaan, 2021).

But seeing the reality that is happening at this time, amid a pandemic that has been going on for approximately two years, requires students to learn from home. Of course, this is an obstacle in teaching morals (Ikhwan, Anwar and Mahmudah, 2021). The non-meeting between educators and students in the room causes this moral teaching not to work and face-to-face learning. Of course, the role of educators in schools must be taken over by parents who are supposed to be the first educators for children. However, sometimes there are still many parents who do not understand the method of teaching morals to children to be maximally successful (Angelica and Munawir, 2021). Through this paper, it is hoped that parents can follow the moral teaching method that has been applied to this MAN 2 Kudus educational institution so that they can apply it at home to be taught to children or at least if they cannot use it as a whole, at least parents can learn moral education methods in MAN 2 Kudus through the school boarding system and applying several methods that are considered relevant and by the condition of the child.

\section{METHOD}

The type of research is qualitative research (field research), the kind of approach in this research is a descriptive qualitative approach. Namely, research that studies phenomena in their natural environment. Therefore, the object of the study is an object in the field that can provide information about the research study. The study was conducted at MAN 2 Kudus, located on Jalan Mijen, Pambatan Kidul, Kec. Kaliwungu, Kudus Regency, Central Java. The reason for researching MAN 2 Kudus is because this school already has a Boarding School that supports moral formation (Sugiono, 2014).

The primary data sources in qualitative research are words and actions, and the rest are additional data such as documents and others. The primary data sources are recorded through written notes or through taking photos.

Because this research has a characteristic that lies in its purpose, which is to describe everything related to the overall activity, so this approach is a research procedure that produces descriptive data in the form of written or spoken words from people and behaviours that can be observed and directed at the natural setting and the individual holistically (whole) (Dedy Mulyana, 2010). 


\section{RESULT AND DISCUSSION}

\section{Moral Education Boarding School Students Through MAN 2 Kudus}

\section{Teaching Material and Yellow Book}

for morality in boarding material introduced through the book of al-arba'in Koran alnawawiyyah, Riyadul Badiah, NaShoihul Ibad, Ta'lim Muta'allim and others. The recitation of the text is carried out after boarding school students perform the morning prayer in the congregation. Activities carried out in each class.

\section{Exemplary and Habituation Are}

supporters of the formation of noble character. The ideal method is applied by giving suitable examples in behaviour, nature, and way of thinking (Anwar, 2021). At the boarding school, MAN 2 Kudus, apart from students who must have a noble character, also need figures who can serve as role models. Implementing an excellent exemplary method or uswah repertoire for students begins with caregivers who provide examples such as obligatory prayers in congregation, behave and speak honestly, give examples of not being ghasab. The exemplary method by providing a good example or uswah hasanah to students in all respects. For example, behaving and speaking honestly, the character is not anxious with the technical rules. All students give names to their sandals.

Tabel 1. Student Activities While At The Boarding School

\begin{tabular}{ccc}
\hline No & Hours Of & Activity \\
\hline $\mathbf{1 .}$ & $03.30-04.15$ & Tahajjud Prayer \\
\hline $\mathbf{2 .}$ & $04.15-04.45$ & Subuh Prayer in Congregation \\
\hline $\mathbf{3 .}$ & $04.45-05.30$ & Bible Study / English Vocab \\
\hline $\mathbf{4 .}$ & $05.30-06.30$ & Personal Activities \\
\hline $\mathbf{5 .}$ & $07.00-17.00$ & Formal Activities at Madrasa \\
\hline $\mathbf{6 .}$ & $17.00-17.30$ & Personal Activities \\
\hline $\mathbf{7 .}$ & $17.45-18.30$ & Maghrib Prayer And Book Study \\
\hline $\mathbf{8 .}$ & $18.30-19.00$ & Dinner \\
\hline $\mathbf{9 .}$ & $19.00-19.30$ & Isya Prayer \\
\hline $\mathbf{1 0}$ & $19.30-21.30$ & Independent Learning / Achievement Clinic \\
\hline $\mathbf{1 1}$ & $21.30-03.30$ & Sleep \\
\hline
\end{tabular}

The activity data above shows that all activities in the MAN 2 Kudus Boarding School are not useless. Here time is used as much as possible. When students wake up in the morning until they go back to sleep, all are put to good use.

\section{Advice}

The advice method is a method of moral education whose implementation is by advising students who violate the rules not to repeat the violation. Advice is given to students who break the rules.

\section{Punishment and Reward}

This method is a method of giving rewards in the form of exemption from punishment or praise for students who carry out applicable regulations and ta'zir penalties for students who violate the rules. Teachers should not be stingy in the form of rewards, even if only in the form of a smile. Punishment is also given depending on the violation (Setiawan, 2018). 
Penalties are given to students depending on the violation. An example of running away is when a child does not speak politely and writes istighfar 200 times. Penalties are given to provide a deterrent effect to students. Rewards for students who obey the rules are given trust by caregivers, such as priests, when praying together. The application of the reward and punishment method also applies to boarding school students who do not comply with the fardhu prayer regulations in the congregation. Punishment is given when the child is late for the community, running three times after Fajr. The reward is in the form of praise and awards for exemplary students (Darimi and Ismail, 2019).

\section{Model of Moral Application of MAN 2 Kudus Boarding School at Home}

There are several processes to form good morals. According to Nasirudin, to shape students' morals, three methods need to be used: First, through understanding (science). This understanding is done by telling about the nature and values of goodness. The process of learning is in the form of knowledge and information about the importance of noble character. With experience, one becomes aware, is converted, and is compelled to be virtuous. Second, through habituation (charity). Habituation is very necessary for the formation of morals because it maintains the morals that have been attached to a person. A person's heart is often volatile even though it seems that his actions are one with himself. Third, through a good example (Uswah Hasanah). The method of moral education, for instance, is a supporter of the formation of noble character. The exemplary method is applied by setting a good example if the closest people such as family, teachers and environmental support who always use good examples will support children to make choices that are in good values (Ikhwan, Aderi Che Noh and Iman, 2020).

\section{Exemplary during a pandemic}

What is meant by the exemplary method is a method of education by giving suitable examples to students, both in words and deeds.

Exemplary is one of the educational methods applied by Rasulullah and has the most influence on the success of conveying his missionary mission. Many academic experts argue that education by example is the most effective method. Abdullah Ulwan, for instance, as quoted by Henry Noer Aly, said that educators would find it easy to communicate their message orally. However, the child will find it challenging to understand the message if the educator does not give an example of the letter he conveys.

In this case, the reinforcement given by the parents is the best example in the child's view, because all their actions, manners, manners of dress and speech of parents will always be noticed and will be imitated by children. Therefore, parents are expected to give good examples in the right way. Sometimes in providing suitable measures, parents sometimes underestimate or pay less attention to the delivery process even though the output is the same. During the pandemic, the role model that used to have to go out, shake hands before leaving the house changed according to the health protocol regulated by the government. Parents continue to provide examples and understanding for families to continue to act intelligently in religion and state (Rajab, 2021). 


\section{Habituation is a Pandemic Period}

Habituation, according to MD Dahlan, as quoted by Hery Noer Aly, is a process of teaching habits. At the same time, habits (habits) are ways of acting that are persistent, uniform and almost automatic (almost not realized by the perpetrators). This habitation aims to make it easier to do it because someone who already has certain habits will do it quickly and happily (Afrilia and Indriya, 2020).

Efforts made by parents for children are by habituating prayers on time, habituating sunnah prayers, reading the Koran more regularly and deepen the knowledge of Islam, apply Islamic education at home through daily activities, multiply blessings and shalawat to Allah and more often give positive examples to children amid the COVID19 pandemic such as doing riyadhoh which aims to maintain.

\section{Punishment and Reward}

Punishment is a punishment for someone's behaviour that violates the rules and vice versa. A reward is a reward for kindness done by someone. Parents can do this punishment and reward their children. If the child makes a mistake, the parents can give punishment with the intention that the child feels deterred and does not dare to do this repeatedly. Punishment can be done by parents using: verbal warnings or even physically if it is thought that the child's mistake is fatal enough. Say when a child says bad things or dirty words. Parents can warn children verbally. However, if the child is still not deterred, parents can act physically, but this is still within the proper corridor (not torturing the child) (Ikhwan, 2017).

Then there is a reward, and this reward is given with the intention that the child feels happy that he has done a good thing, and it is hoped that the child will always do good for the future. Of course, this reward also has its limits. We must not give too much reward, and if the reward offered is in the form of goods, it would be better not to give it continuously, this is to avoid the purpose of the child doing good is to get a gift from her parents. Just giving him praise that is not excessive can also be called a reward.

\section{CONCLUSION}

Based on research on Moral Education methods in Boarding School MAN 2 Kudus, it can be concluded that the technique used is by teaching and habituation. Teaching is carried out through the method teaching book yellow which is carried out after maghrib prayer and habituation can be seen from the student activity schedule, in addition to these two methods, there are also methods of habituation, exemplary, advice, punishment reward which basically can be applied to children's moral education during the pandemic., which of course, is adapted to the child's condition and the situation that is happening.

\section{REFERENCES}

[1] Afrilia, H. and Indriya, I. (2020) 'Internalisasi Pendidikan Karakter Islami Anak Ditengah Pandemi Covid-19', Al-Fikr: Jurnal Pendidikan Islam, 6(2), pp. 46-52.

[2] Angelica, D. E. and Munawir (2021) 'Identifikasi Problematika dan Solusi Pembelajaran Pendidikan Agama Islam di Masa Pandemi', Journal of Chemical Information and Modeling, 8(1), pp. 1689-1699. 
[3] Anwar, S. (2021) 'Internalisasi Nilai Pendidikan Akhlak dalam Surat Al-Hujurat Tafsir fi ZIlalil Qur'an', JIE: Journal of Islamic Edication, 6(1), pp. 1-12.

[4] Darimi, I. and Ismail, B. (2019) 'Education "Jaman Now": Reward and Punishment Review', JPP (Jurnal Pendidikan dan Pembelajaran), 25(2), pp. 4750. doi: 10.17977/um047v25i12018p047.

[5] Houwer, J. De, Barnes-Holmes, D. and Moors, A. (2013) 'What Is Learning? On the Nature and Merits of a Functional Definition of Learning', Psychonomic Bulletin \& Review, 20(4), p. 631.

[6] Hutabarat, B. A. (2017) 'Isu Agama dalam Sisdiknas No.20 Tahun 2003: Meninjau Kembali Jalan Demokrasi Pendidikan Nasional', Societas Dei: Jurnal Agama dan Masyarakat. doi: 10.33550/sd.v1i1.50.

[7] Ikhwan, A. (2017) 'Development Of Quality Management Islamic Education In Islamic Boarding School (Case Study Madrasah Aliyah Ash Sholihin)', Al-Hayat: Journal of Islamic Education, 01(01), pp. 1-27.

[8] Ikhwan, A., Aderi Che Noh, M. and Iman, N. (2020) 'Implementation of The Tahfidzal-Qur'an Curriculum at The Tahfidz Malaysia Boarding School', Journal of Critical Reviews, 7(8), pp. 866-870. doi: http://dx.doi.org/10.31838/jcr.07.08.185.

[9] Ikhwan, A., Anwar, S. and Mahmudah, N. (2021) 'Tahsin and Tahfidz Learning System at Integrated Islamic Elementary School (SDIT) Insan Madani During the Pandemic Covid-19', Al-Hayat: Journal of Islamic Education (AJIE), 5(1), pp. 111.

[10] Kementerian Pendidikan dan Kebudayaan (2021) 'JDIH Kementerian Pendidikan Dan Kebudayaan RI'.

[11] Rajab, H. (2021) Pendidikan Akhlak Masa Pandemi. Jakarta: Osfpreprints.

[12] Setiawan, W. (2018) 'Reward Dan Punishment Dalam Perspektif Pendidikan Islam', Al-Murabbi, 4(2), pp. 184-201. Available at: https://d1wqtxts1xzle7.cloudfront.net/55758886/Artikel_Reward_and_Punishment _Dalam_Perspektif_Pendidikan_Islam.......Al_Murabbi_STIT_KP_Ngawi.pdf?151 $8184112=\&$ response-content disposition=inline\%3B+filename\%3DReward_and_Punishment_dalam_Perspektif _P.pdf\&Ex.

[13] Sugiono (2014) Metode Penelitian Pendidikan (Pendekatan Kuantitatif, Kualitatif, Dan R\&D. Bandung: Alfabeta.

[14] Sugiyanto, Kartowagiran, B. and Jailani (2015) 'Pengembangan Model Evaluasi Proses Pembelajaran Matematika Di Smp Berdasarkan Kurikulum 2013', Jurnal Penelitian dan Evaluasi Pendidikan, 19(1), p. 83.

[15] Tobroni (2018) Memperbincangkan Pemikiran Pendidikan Islam: Dari Idealisme Substantif Hingga Konsep Aktual. Jakarta: Kencana. 